\title{
Virulence and nucleotide sequence analysis of marine viral haemorrhagic septicaemia virus following in vivo passage in rainbow trout Onchorhynchus mykiss
}

\author{
M. Snow*, C. O. Cunningham \\ Fisheries Research Services Marine Laboratory, PO Box 101, Victoria Road, Aberdeen AB11 9DB, United Kingdom
}

\begin{abstract}
A marine isolate of viral haemorrhagic septicaemia virus (VHSV) (860/94) was passaged in triplicate through sequential batches of rainbow trout via an intra-peritoneal infection route, without amplification in tissue culture. Following 5 passages, the VHSV glycoprotein gene was amplified directly from fish tissue homogenates and the consensus sequence compared to that of the original tissue culture isolate. Virus was also recovered directly from pools of kidney and spleen material after 5 passage events, and its virulence compared to that of unpassaged material by intra-peritoneal infection. Following passage in rainbow trout, isolate 860/94 exhibited a higher virulence for rainbow trout than unpassaged material. Sequence comparisons identified no difference in the consensus sequence of the glycoprotein gene following in vivo passage. The mechanisms responsible for the observed increase in virulence of isolate 860/94 following passage in rainbow trout thus remain unknown. The possibility that viral isolates may exhibit an increased virulence following passage in novel host species does, however, have important implications with regard to the epidemiology of this important fish pathogen.
\end{abstract}

KEY WORDS: Viral haemorrhagic septicaemia virus · VHSV • Novirhabdovirus · Rainbow trout • In vivo passage $\cdot$ Glycoprotein

\section{INTRODUCTION}

Rainbow trout Onchorhynchus mykiss were traditionally thought to be the main host for viral haemorrhagic septicaemia virus (VHSV), a pathogen that remains responsible for significant losses to the trout aquaculture industry in Europe. The isolation of VHSV from an increasing number of wild marine species has, however, indicated the existence of an enzootic virus in both the European and North American marine environments (Meyers et al. 1992, 1994, Traxler \& Kieser 1994, Meyers \& Winton 1995, Smail 1995, Mortensen et al. 1999). The fact that VHSV has not become established in North American rainbow trout, coupled to genetic evidence based on the comparison of North American and European marine isolates, has

*E-mail: snowm@marlab.ac.uk suggested that the 2 lineages became separated a long time before fish farming was established on both continents (Benmansour et al. 1997). Thus, VHSV pathogenic for European rainbow trout may have evolved from the marine environment where it existed, like the North American strain of VHSV does today (Meyers \& Winton 1995). Indeed, a genetic link between VHSV isolates recovered from the Baltic Sea and isolates responsible for mortality in rainbow trout in continental Europe has been demonstrated (Snow et al. 1999). The feeding of unpasteurised raw marine fish to intensively cultured fish, a practise which was widespread in the early days of the industry, has been proposed as a likely route through which VHSV may have been introduced to freshwater rainbow trout (Meyers \& Winton 1995).

Single-stranded RNA viruses, such as VHSV, exhibit high mutation rates, resulting in the production of 
'quasispecies' populations containing a large number of different genotypes (Steinhauer \& Holland 1987, Winton 1992). Under stable conditions, the average (consensus) sequence of the population is probably reflective of the most fit genotype and is relatively stable (Jørgensen et al. 1995). If novel selection pressures are imposed, genotypes within the quasispecies population with a higher fitness under these conditions may predominate, resulting in a corresponding shift to produce a new consensus sequence. In such evolving viral populations, single point mutations can lead to altered phenotypic characteristics, including changes in virulence, as has been demonstrated by selection of neutralising antibody escape mutants, for a number of RNA viruses including VHSV and IHNV (infectious haematopoietic necrosis virus) (Kim et al. 1994, Béarzotti et al. 1995).

The advent of fish husbandry has introduced a number of selective pressures including high rearing densities, the continuous addition of susceptible fish, differing temperatures, and the presence of fish immunised by exposure to wild type virus (Winton 1992). Furthermore, intensive fish culture has exposed animals to new environments and their viruses to new host species. Given these selective pressures, it seems likely that fish viruses will evolve most rapidly in intensive culture systems (Winton 1992). Thus the highly pathogenic nature of the European freshwater strains of VHSV may be a result of the exposure of rainbow trout, an introduced species, into the stressful environment of intensive culture, and the high rate of mutation inherent in all rhabdoviruses (Meyers \& Winton 1995).

An improved understanding of the mechanisms which drive the evolution of fish rhabdoviruses is fundamental to assessing the risk posed to future culture operations by the existence of marine reservoirs of virus. This study was therefore initiated to investigate the effect on the glycoprotein gene sequence and virulence of in vivo passage of a marine VHSV isolate through a freshwater host species. The glycoprotein gene was selected for sequencing since it is known that this gene can play a role in the virulence of VHSV (Béarzotti et al. 1995, Benmansour \& de Kinkelin 1997).

The reliance on amplification in tissue culture was avoided since the effects on viral quasispecies populations of amplification on fish cell monolayers remain unknown. Tissue culture isolation and amplification may in itself represent a novel selective pressure, resulting in the consensus sequence and thus the phenotypic characteristics of a virus isolate differing from those found in the original host tissue. Indeed, differences in the glycoprotein gene sequence of rabies virus isolated in tissue culture or amplified directly from clinical material have been demonstrated (Benmansour et al. 1992).

\section{METHODS}

Cell culture and virus propagation. The isolate of VHSV used in this study was 860/94, which originated from turbot farmed at Gigha, West Scotland (Ross et al. 1994). The epithelioma papulosum cyprini (EPC) (Fijan et al. 1983) cell line was used to propagate virus according to methods previously described (Snow et al. 1999). Virus was stored following a total of 3 passages on EPC cells using a low multiplicity of infection (MOI) $(<0.01)$, and titrated using the tissue culture infectious dose method $\left(\right.$ TCID $_{50}$ ) (Reed \& Muench 1938, Burleson et al. 1992).

Pathogen-free fish. Rainbow trout (2 to $4 \mathrm{~g}$ ) were produced at the FRS Marine Laboratory, Aberdeen, Scotland. These fish were produced from sperm and eggs obtained from a single male and female fish respectively. Prior to each infection, 10 fish were sacrificed and the organs of each fish examined for the presence of infectious pancreatic necrosis virus (IPNV), IHNV and VHSV using methods described previously (Snow et al. 1999).

In all infection experiments, fish were allowed to acclimate for $7 \mathrm{~d}$ and were starved for $24 \mathrm{~h}$ prior to infection. Water temperatures were maintained at $10^{\circ} \mathrm{C}$ for the duration of all experimental infections and the tanks supplied with $11 \mathrm{~min}^{-1}$ of freshwater. Inoculum volumes for intra-peritoneal injections were $50 \mu \mathrm{l}$ in all cases.

Infection of rainbow trout with VHSV isolate 860/94. Rainbow trout were held at a stocking density of 50 fish $\operatorname{tank}^{-1}$, in each of eight $30 \mathrm{l}$ aquaria. From each of 2 tanks, fish were removed and injected intraperitoneally with $1.58 \times 10^{7} \mathrm{TCID}_{50} \mathrm{fish}^{-1}$ of isolate 860/94 (high dose). Fish from 2 further sets of duplicate tanks were injected with doses of $1.58 \times 10^{5}$ TCID $_{50}$ (medium dose) and $1.58 \times 10^{3} \mathrm{TCID}_{50}$ (low dose) respectively. In the remaining 2 tanks, fish were injected with Glasgow modified minimal essential medium supplemented with $10 \%$ foetal bovine serum (GMEM-10) (Life Technologies) to serve as a control group. Fish were monitored and mortalities recorded daily for the duration of the challenge (60 d).

An additional 2 tanks were each stocked with 75 rainbow trout, which were injected with $1.58 \times 10^{7}$ $\mathrm{TCID}_{50}$ virus fish ${ }^{-1}$. At each day post-infection for $10 \mathrm{~d}$, 5 fish from each tank were sacrificed and all kidney and spleen material was aseptically removed. All tissue from the 10 fish sampled at each timepoint was pooled and processed for the recovery of virus. The viral titre of the resulting supernatant was determined by TCID $_{50}$ titration on EPC cells.

Recovery of virus from fish tissue. Tissues were homogenised and diluted 1:10 (w/v) in GMEM-10 supplemented with $0.2 \%$ gentamycin. Following centrifu- 
gation of samples at $3000 \times g$ for $10 \mathrm{~min}$, the resulting supernatants were filtered through a $0.22 \mu \mathrm{m}$ filter and stored at $-80^{\circ} \mathrm{C}$.

Passage of VHSV isolate 860/94 in rainbow trout. Isolate 860/94 was subjected to in vivo passage in 3 independent lines of rainbow trout originating from the same homogeneous fish stock. Fifty trout were held in each of four 301 tanks (A, B, C and D), and fish from tanks A to $\mathrm{C}$ were removed, anaesthetised and injected intra-peritoneally with $1.58 \times 10^{7} \mathrm{TCID}_{50} \mathrm{fish}^{-1}$ of tissue-culture grown isolate 860/94 (pass 3). Fish from tank D were injected with GMEM-10 to serve as controls. At 3 d post infection, 25 fish from each of tanks A to D were sacrificed and all kidney and spleen tissue was aseptically removed. A single tissue pool was made from the fish harvested from each tank and processed for the recovery of virus. The supernatants prepared following the processing of tissue pools obtained from each of tanks A to D at $3 \mathrm{~d}$ post-infection were used to inject a second batch of 50 rainbow trout (pass 2 ), held in a further 4 tanks. Pass 2 fish were sacrified at $3 \mathrm{~d}$ post-infection and the resulting tissue pools processed for virus recovery. This entire process was repeated until isolate 860/94 had been passaged independently in triplicate through 5 successive batches of rainbow trout. At each passage level, the inoculum volume remained constant $(50 \mu \mathrm{l})$ and the dose received by each batch of fish was determined by TCID $_{50}$ titration of the harvested supernatants on EPC cells. The final recovered virus was stored at $-80^{\circ} \mathrm{C}$ and a single aliquot titrated following a freeze-thaw cycle.

Infection of rainbow trout with VHSV of differing passage histories. Rainbow trout were infected with the original tissue-culture-grown virus and with virus that was recovered following in vivo passage in rainbow trout. Ten 301 aquaria were each stocked with 50 rainbow trout. Fish from 4 sets of duplicate tanks were injected intra-peritoneally with $50 \mu \mathrm{l}$ of virus-containing or control supernatant obtained after 5 in vivo passages of strain 860/94 in rainbow trout (passage lines A, B, C and D). Virus obtained from each of lines A, B and $C$ was diluted with G-MEM to the concentration of the lowest sample, resulting in an effective dose of $2.5 \times 10^{6} \mathrm{TCID}_{50} \mathrm{fish}^{-1}$. An equivalent dose of strain 860/94 which had not been subject to in vivo passage was administered intra-peritoneally to 50 fish in each of a further 2 tanks. Fish in the remaining 2 aquaria were injected with $50 \mu$ l of passage line D material (control). Fish were monitored and mortalities recorded daily for the duration of the challenge (60 d).

Statistical analysis. Statistical analysis was conducted using a generalised linear regression as implemented in the Genstat 5 (Release 3) computer software. The effect of treatment was assessed based on binomially distributed data using the logistic link func- tion. Probability values were adjusted for the number of comparisons by multiplying them by the number of tests performed according to the Bonferroni method (Hsu 1996).

Extraction of RNA. Total RNA was extracted from EPC cells infected with VHSV and from fish tissue homogenates obtained following 5 passages of isolate 860/94 in rainbow trout (passage lines A, B, C and D). RNA was extracted using the TRIzol reagent according to the manufacturer's recommendations (Life Technologies). The RNA was resuspended in water treated with diethyl pyrocarbonate (Sigma) and its concentration determined by measuring the optical density at $260 \mathrm{~nm}$.

Reverse transcriptase PCR. RNA (1 $\mu \mathrm{g})$ was reverse transcribed in a reaction volume of $20 \mu \mathrm{l}$ in the presence of $15 \mathrm{U}$ of avian myeloblastosis virus (AMV) reverse transcriptase; $5 \mathrm{mM} \mathrm{MgCl}_{2} ; 1 \mathrm{mM}$ of dATP, dTTP, dCTP and dGTP; $1 \mathrm{U} \mathrm{l}^{-1}$ RNasin ribonuclease inhibitor; $1 \times$ transcription buffer $(10 \mathrm{mM}$ Tris- $\mathrm{HCl}[\mathrm{pH} 8.8$ at $25^{\circ} \mathrm{C}$ ], $50 \mathrm{mM} \mathrm{KCl}$, and $0.1 \%$ Triton X-100) (Life Technologies); $100 \mathrm{pmol}$ primer GFOR (5' ATG GAA TGG AAC ACT TTT TTC 3'); and 100 pmol primer GREV (5' TCA GAC CGT CTG ACT TC TGG A 3'). PCR amplifications were performed in a total volume of $100 \mu \mathrm{l}$. Reactions contained $1 \times$ PCR buffer $\left(160 \mathrm{mM}\left(\mathrm{NH}_{4}\right)_{2} \mathrm{SO}_{4}\right.$, $670 \mathrm{mM}$ Tris- $\mathrm{HCl}\left[\mathrm{pH} 8.8\right.$ at $\left.25^{\circ} \mathrm{C}\right], 0.1 \%$ Tween-20) (Bioline); $1.5 \mu \mathrm{MgCl}_{2}$ (50 mM) (Sigma) and the entire volume of the reverse transcription reaction. The reactions were overlaid with mineral oil (Sigma) and incubated at $95^{\circ} \mathrm{C}$ for $5 \mathrm{~min}$. Tubes were subsequently held at $85^{\circ} \mathrm{C}$ for the addition of $1 \mu \mathrm{l}$ Biotaq polymerase (5 U) (Bioline). Thirty-five cycles of denaturing $\left(94^{\circ} \mathrm{C}, 1 \mathrm{~min}\right)$, annealing $\left(50^{\circ} \mathrm{C}, 1 \mathrm{~min}\right)$, and extension $\left(72^{\circ} \mathrm{C}, 1.75 \mathrm{~min}\right)$, followed by a single final extension step $\left(72^{\circ} \mathrm{C}, 5 \mathrm{~min}\right)$ were performed. Following PCR, a $10 \mu$ l aliquot was analysed by electrophoresis on a $1.5 \%$ (w/v) agarose gel.

Cloning. PCR products were purified from agarose gel using the Geneclean III kit according to the manufacturer's instructions (Bio 101). For each glycoprotein gene sequence determined, purified products of 3 independent RT-PCR amplifications were cloned into vector pGEM-T according to the manufacturer's protocol (Promega).

DNA purification and sequencing. Plasmids were purified using the Wizard Miniprep DNA purification system (Promega). Nucleotide sequence for each G gene was obtained from triplicate clones in the forward and reverse orientations. Cycle sequencing reactions were conducted using an ABI PRISM dRhodamine Terminator Cycle Sequencing Ready Reaction Kit and analysed using an Applied Biosystems model 373A sequencer and ABI Prism collection software according to the manufacturer's instructions (PE Applied Biosystems). 


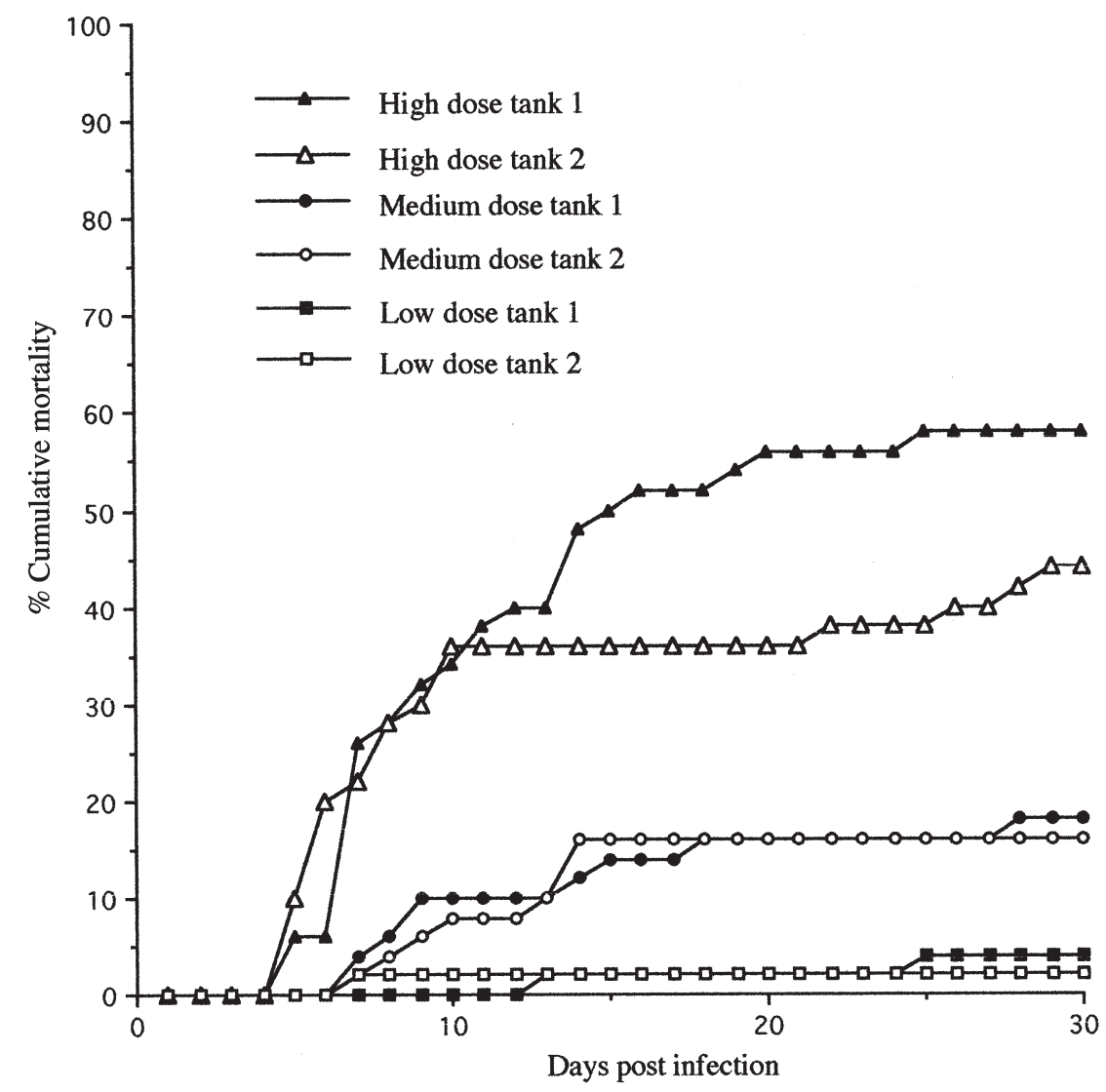

Fig. 1. VHSV infecting Oncorhynchus mykiss. Percent cumulative mortalities recorded in individual tank replicates of rainbow trout infected with high $\left(1.58 \times 10^{7}\right.$ TCID $_{50}$ fish $\left.^{-1}\right)$, medium $\left(1.58 \times 10^{5} \mathrm{TCID}_{50} \mathrm{fish}^{-1}\right)$ and low doses $\left(1.58 \times 10^{3} \mathrm{TCID}_{50} \mathrm{fish}^{-1}\right)$ of VHSV isolate $860 / 94$ via the intraperitoneal (i.p.) route. Virus was administered in an inoculum volume of $50 \mu \mathrm{l}$ in all cases. No mortalities were recorded after $30 \mathrm{~d}$ post-infection or in either of the duplicate control tanks for the duration of the challenge (60 d) (data not shown)

\section{RESULTS}

\section{Infection of rainbow trout with VHSV isolate $860 / 94$}

Rainbow trout were confirmed, by virological examination, to be free from VHSV, IHNV and IPNV prior to infection. Cumulative percent mortalities of replicate tanks of trout challenged with different doses of isolate 860/94 are detailed in Fig. 1. Mortalities commenced at Day 5 post-infection in fish infected with the highest viral dose, and at $7 \mathrm{~d}$ post infection in groups infected with the medium and low doses. Average peak mortalities reached 51, 17 and 3\% in the groups infected with the high, medium and low doses of VHSV isolate 860/94, respectively. The titres of virus recovered from the organs of fish following infection with a high dose of virus are detailed in Fig. 2. The highest titre of virus recoverable peaked at 3 to $4 \mathrm{~d}$ post infection at a level of 3.83 to $5.18 \times 10^{8}$ TCID $_{50} \mathrm{~g}^{-1}$ fish tissue.

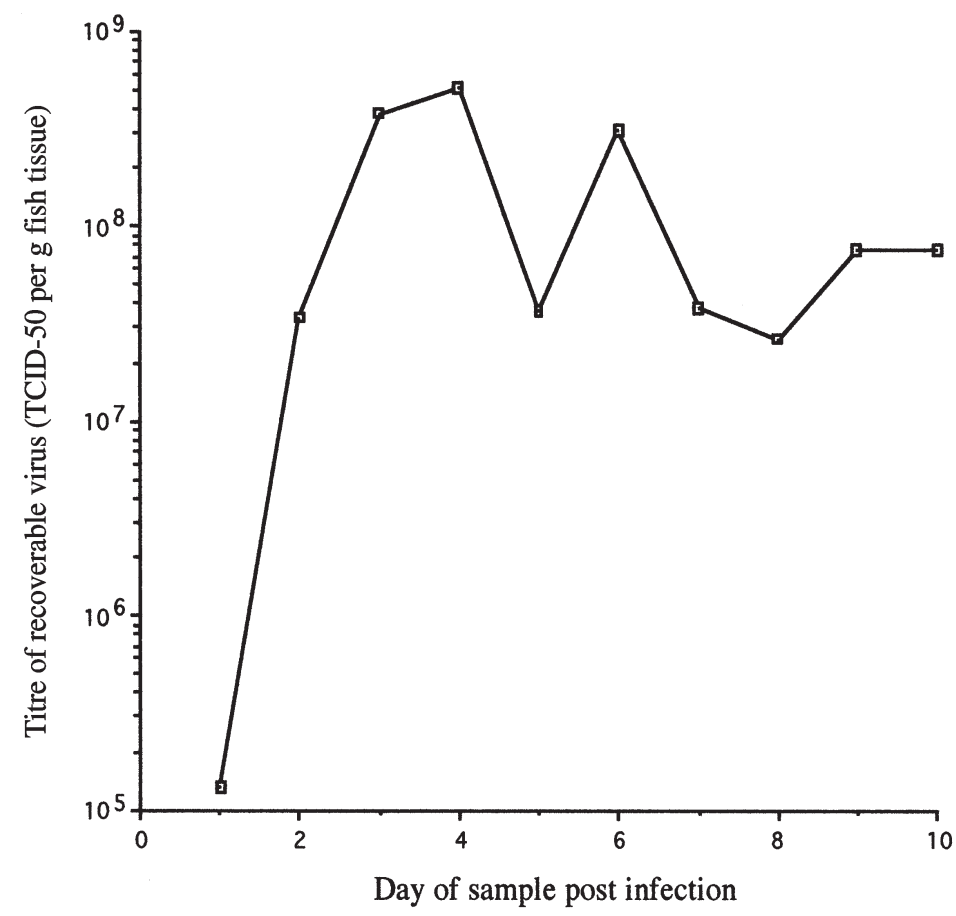

Fig. 2. VHSV infecting Oncorhynchus mykiss. Titres of virus recoverable from the organs (kidney and spleen) of rainbow trout following intra-peritoneal infection with a high dose of VHSV isolate 860/94 $\left(1.58 \times 10^{7}\right.$ TCID $_{50}$ fish $\left.^{-1}\right)$ 
Table 1. VHSV infecting Onchorhynchus mykiss. Viral doses $\left(\mathrm{TCID}_{50} \mathrm{fish}^{-1}\right.$ ) administered to and virus titres $\left(\mathrm{TCID}_{50} \mathrm{ml}^{-1}\right)$ recoverable from different passage lines of sequential batches of rainbow trout (passage lines A, B, C and D) infected with isolate 860/94. Virus was administered in an inoculum volume of $50 \mu \mathrm{l}$ in all cases

\begin{tabular}{|lccccccc|}
\hline $\begin{array}{l}\text { Passage } \\
\text { number }\end{array}$ & Dose & $\begin{array}{c}\text { A } \\
\text { Recoverable } \\
\text { virus }\end{array}$ & Dose & $\begin{array}{c}\text { B } \\
\text { Recoverable } \\
\text { virus }\end{array}$ & Dose & $\begin{array}{c}\text { C } \\
\text { Recoverable } \\
\text { virus }\end{array}$ & $\begin{array}{c}\text { D } \\
\text { Recoverable } \\
\text { virus }\end{array}$ \\
\hline 1 & $1.58 \times 10^{7}$ & $5.01 \times 10^{8}$ & $1.58 \times 10^{7}$ & $7.50 \times 10^{8}$ & $1.58 \times 10^{7}$ & $2.46 \times 10^{7}$ & 0 \\
2 & $2.51 \times 10^{7}$ & $1.32 \times 10^{8}$ & $3.25 \times 10^{6}$ & $2.61 \times 10^{8}$ & $1.23 \times 10^{7}$ & $7.50 \times 10^{8}$ & 0 \\
3 & $0.66 \times 10^{7}$ & $2.46 \times 10^{9}$ & $1.31 \times 10^{7}$ & $7.50 \times 10^{7}$ & $3.25 \times 10^{7}$ & $2.46 \times 10^{7}$ & 0 \\
4 & $1.23 \times 10^{8}$ & $7.50 \times 10^{7}$ & $3.25 \times 10^{6}$ & $2.00 \times 10^{7}$ & $1.23 \times 10^{6}$ & $7.50 \times 10^{7}$ & 0 \\
5 & $3.25 \times 10^{6}$ & $3.83 \times 10^{8}$ & $1.00 \times 10^{6}$ & $5.10 \times 10^{7}$ & $3.75 \times 10^{6}$ & $2.28 \times 10^{8}$ & 0 \\
\end{tabular}

\section{Passage of VHSV isolate $860 / 94$ in rainbow trout}

Titres of virus recovered from each fish passage and the doses administered to each successive batch of rainbow trout are detailed in Table 1 . Virus was recovered with a titre of over $1 \times 10^{7} \mathrm{TCID}_{50} \mathrm{ml}^{-1}$ in all passage levels in lines A to $C$, ensuring that a dose $\geq 1 \times 10^{6}$ TCID $_{50}$ fish $^{-1}$ was received by all fish infected throughout the study. Virus was recovered following 5 passages with a titre greater than $5 \times 10^{7} \mathrm{TCID}_{50} \mathrm{ml}^{-1}$ in each of passage lines A to C.

\section{Infection of rainbow trout with VHSV of differing passage histories}

Cumulative mortalities for individual tanks of rainbow trout that were challenged with a dose of isolate $860 / 94$ of different passage histories are detailed in Fig. 3. Mortality commenced at Day 6 in all tanks and at the end of the challenge period cumulative percent mortalities in individual tanks ranged from 34 to $82 \%$. To investigate the effect of treatment, linear regression was conducted with a single main effect, that is, mor-
Fig. 3. VHSV infecting Oncorhynchus mykiss. Percent cumulative mortalities recorded in individual tank replicates of rainbow trout infected with an equal dose $\left(2.5 \times 10^{6} \mathrm{TCID}_{50}\right.$ fish $^{-1}$ ) of the original batch isolate $860 / 94$ or with batches of virus subjected to successive in vivo passage in rainbow trout (lines A, B and C)

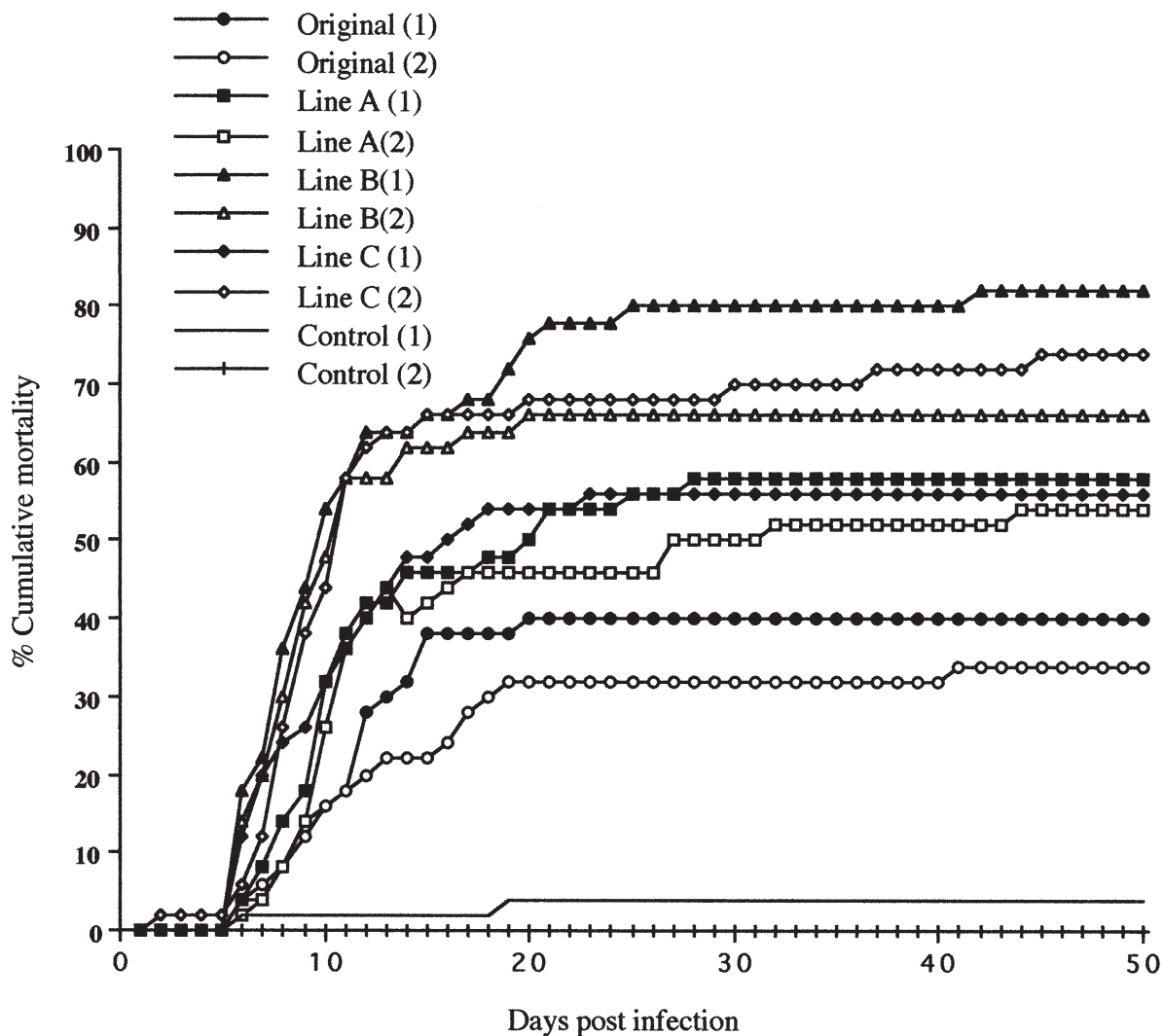




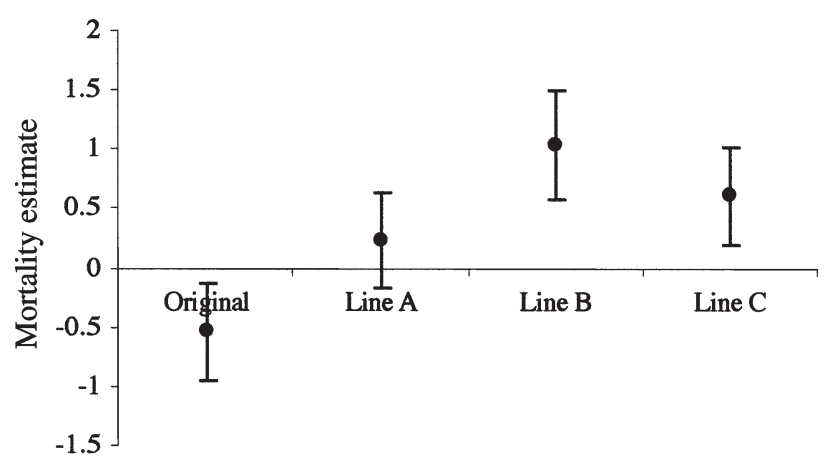

Fig. 4. VHSV infecting Oncorhynchus mykiss. 95\% confidence intervals for estimates of mortality in rainbow trout following infection with the original batch of isolate 860/94 or with batches of virus subjected to successive in vivo passage in rainbow trout (lines A, B and C). Exact $95 \%$ confidence limits were calculated using the StatXact statistical package, which is designed to deal with non-parametric inference

tality caused by treatment. This gave a residual deviance of 7.51 on 4 degrees of freedom, indicating no overdispersion or lack of fit. A highly significant treatment effect was identified $(p<0.001)$. Estimates of mortality \pm 2 SE for each treatment were plotted on the logistic scale (Fig. 4). This indicated that mortalities obtained using virus from lines B and C were significantly higher than those obtained using the original viral batch $(\mathrm{p}=0.05)$. In contrast, mortality using line A material was not significantly different from that obtained using the original viral batch. No significant differences were noted between mortality estimates of lines A, B and C. These results were confirmed by comparison of the probability values which were obtained for the mortality estimates of all treatments, adjusted for the number of comparisons using the Bonferroni method (Table 2). These results indicated that the only significant differences were between the unpassaged strain and line B $(p<0.006)$ and the unpassaged strain and line $C(p<0.006)$.

\section{Cloning and sequence determination of the VHSV G-gene prior to passage in rainbow trout}

The consensus sequence of the G-gene deduced from triplicate independently amplified and cloned PCR products is detailed in Fig. 5. Within this sequence, heterogeneity was detected at a total of 7 nucleotide positions, representing an overall mutation frequency of $1.86 \times 10^{-3}$ per nucleotide site. Positions where heterogeneity within the consensus se-
Table 2. Bonferroni p-values for comparison of mortality estimates obtained for rainbow trout infected with isolate 860/94 which had been either unpassaged (original) or subjected to successive in vivo passage in rainbow trout (lines A, B and C)

\begin{tabular}{|lcccc|}
\hline & Original & Line A & Line B & Line C \\
\hline Original & - & 0.042 & $<0.006$ & $<0.006$ \\
Line A & & - & 0.048 & $\begin{array}{c}1.0 \\
\text { Line B }\end{array}$ \\
Line C & & & - & 0.98 \\
\end{tabular}

quence occurred were present in each of the 3 clones sequenced. The consensus sequence obtained for isolate 860/94 was compared to sequence corresponding to virus isolated from the same epizootic available on the EMBL database (Fig. 5). A total of 2 and 11 sites of heterogeneity were detected with respect to the reported sequences of Stone et al. (1997) (isolate 814, Acc. No. U88056) and Benmansour et al. (1997) (isolate Sco 95, Acc. No. Z93405) respectively.

\section{Cloning and sequence determination of the VHSV G-gene following passage in rainbow trout}

The consensus sequence of the $\mathrm{G}$ gene determined following viral passage in 3 independent lines of rainbow trout was identical to that obtained prior to passage (Fig. 5). Heterogeneity was detected at a total of 0,6 and 8 nucleotide sites for sequence obtained in lines $\mathrm{A}, \mathrm{B}$ and $\mathrm{C}$, representing mutation frequencies of $0,1.35 \times 10^{-3}$, and $1.80 \times 10^{-3}$ site $^{-1}$, respectively (Table 3 ). None of these sites of heterogeneity corresponded with sites of heterogeneity detected in the

Table 3. Nucleotide sequences for each of triplicate clones sequenced prior to (original) and following (lines A, B and C) in vivo passage in rainbow trout. Positions indicated refer to nucleotide positions with respect to the open reading frame of the VHSV glycoprotein gene

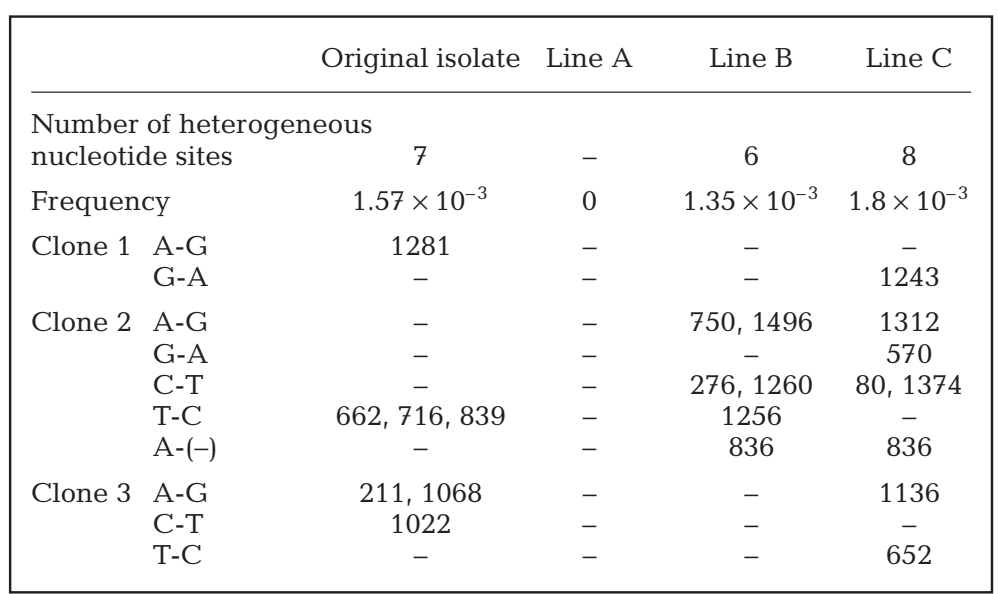



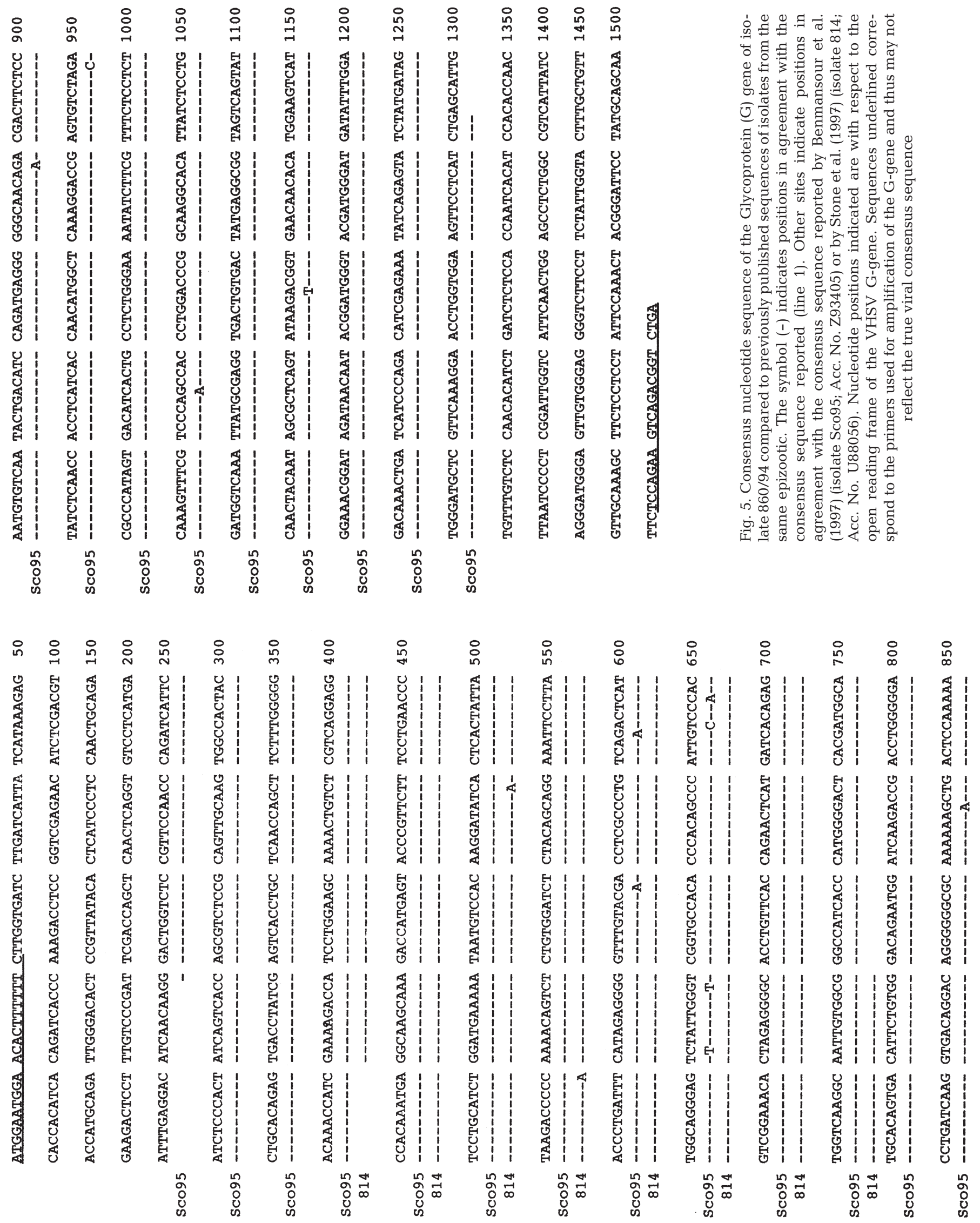
sequence of isolate 860/94, which was determined prior to passage in rainbow trout. All recorded mutations were transitions, with the exception of 2 recorded deletions in individual clones derived from passage lines $\mathrm{B}$ and $\mathrm{C}$ at position 836. The finding that a deletion was recorded at the same site in a single clone originating from 2 independent passage lines was unexpected. No changes in the overall consensus sequence were obtained in passage lines A to C. All the 6 sites of heterogeneity detected in clones derived from passage line B were in a single clone. Eight sites of heterogeneity were detected in clones derived from passage line $\mathrm{C}$, including at least 1 change in each of the triplicate clones sequenced. All sites and nucleotide substitution detected in this study occurred uniquely and were not located at sites of mismatch with the sequences previously published (Benmanour et al. 1997, Stone et al. 1997).

\section{DISCUSSION}

Isolate 860/94 was selected as a representative of the marine isolates of VHSV. Although the origins of this isolate remain unclarified, this isolate has been shown to share a close genetic link with marine isolates from around the British Isles (Snow et al. 1999).

Pathogen-free juvenile rainbow trout were moderately susceptible to VHSV isolate 860/94 following intra-peritoneal infection. This route of infection was selected for in vivo passage since all marine VHSV isolates tested to date, including isolate 860/94, have proven to be avirulent or of low virulence to rainbow trout by immersion infection (N. J. Olesen, Danish Veterinary Laboratory, Aarhus, pers. comm.). Virus was recovered at high titre from the kidney and spleen of experimentally infected rainbow trout at 3 to $4 \mathrm{~d}$ post infection. These organs were selected since it has been proposed that they contain the primary VHSV target cells following infection by this route (Bernard et al. 1983). In addition, recoverable titres have been shown to be higher than from any other organ (Wolf 1988). The isolation of virus from these organs permitted triplicate sets of 5 in vivo passages to be performed, with recovery of virus at sufficient titre to perform comparative infection experiments without additional amplification in tissue culture. Virus was not recovered at levels high enough to perform immersion infections, which would have represented a more natural route of infection for VHSV.

Rainbow trout infected with VHSV isolate 860/94 which had been subjected to in vivo passage in rainbow trout (passage lines B and C) exhibited significantly higher mortailities than fish challenged with the original unpassaged virus. The possibility exists that the titration of fish tissue homogenates determined may have been artefactually low due to the presence of intra-cellular or attached virus. Levels of mortality obtained with virus recovered from passage lines $\mathrm{B}$ and $\mathrm{C}$ were, however, higher than those resulting from challenge with the highest doses achievable using tissue-culture-grown material with over an order of magnitude higher titre in a separate infection experiment. Thus, the observed increase in virulence of isolate $860 / 94$ to rainbow trout is unlikely to be a purely doserelated phenomenon.

The fact that virus could increase in virulence following prolonged exposure to rainbow trout would not be unprecedented. Indeed, the related novirhabdovirus IHNV, a pathogen of juvenile rainbow trout, has evolved into a strain also capable of killing large trout in the commercial hatcheries of Idaho, USA (Winton et al. 1991). There have been relatively few studies characterising the generation of heterogeneity in RNA viruses of animal hosts under controlled experimental conditions (Kurath \& Dodds 1995). Jørgensen et al. (1995) determined the nucleotide substitutions accumulating in the glycoprotein of VHSV isolate F1 during more than 500 passages in fish cell lines. The relative stability of this gene under uniform selection pressure was demonstrated, with the accumulation of only 2 nucleotide substitutions, only 1 of which resulted in a substitution at the amino acid level. Once a cell-culture-adapted strain of a rhabdovirus is selected, it might thus be expected to remain stable unless subjected to novel selection pressures or passaged at a high MOI (Jørgensen et al. 1995).

In order to investigate this phenomenon, the consensus sequence of the glycoprotein gene of isolate 860/94 was determined from virus amplified in cell culture and from the same virus following exposure to a novel selection pressure (exposure to and repeated passage in a novel host species). In obtaining the consensus sequence of isolate 860/94 prior to and following passage in rainbow trout, sporadic sites of heterogeneity were identified, none of which lead to a change in the overall consensus sequence. All recorded nucleotide substitutions were transitions, which usually occur more frequently than transversions (Weiller et al. 1995).

The overall mutation rate was determined as $1.86 \times$ $10^{-3}$ per nucleotide site within the 12 clones sequenced in this study. This result was in accordance with that of Benmansour et al. (1997), who recorded mutation frequencies of $1.2 \times 10^{-3}$ site $^{-1}$ when sequencing 19 clones corresponding to a $741 \mathrm{bp}$ segment of the VHSV Ggene. These workers also determined the cumulative error frequency of reverse-transcriptase and Taq DNA polymerase to be $\geq 6.7 \times 10^{-5}$ site $^{-1}$ based on the sequencing of control cDNAs originating from a single 
clone. Thus, it was deemed likely that most of the recorded mutations in the clones generated from the viral RNA were present in the original virus population (Benmansour et al. 1997). Estimates of the error rates for Taq have been obtained from sequence analysis of clones derived by PCR from templates of a defined sequence to be in the range of 0.81 to $2.55 \times 10^{-3}$ (Smith et al. 1997). Thus, the possibility that at least some of the mutations shown during this study and those of Benmansour et al. (1997), were due to artefactual substitutions cannot be ruled out.

Previously reported sequence data for a VHSV isolate recovered from the same epizootic as isolate 860/94 were not in complete agreement with the sequence produced in this study (Benmansour et al. 1997, Stone et al. 1997). However, alignment of all 3 sequences of isolate 860/94 produced a consensus sequence in complete agreement with the sequence reported in this study. Thus, sites of heterogeneity within previously reported sequences may be due to heterogeneity within the viral population and/or artefacts of the cloning and sequencing process. Given that point mutations can lead to phenotypic variations in RNA viruses, these findings serve to emphasise the biological significance of obtaining the true consensus sequence of viral isolates.

This study is the first to investigate the stability of the consensus sequence of the G-gene of a marine VHSV isolate following in vivo passage in a novel host species. Since no change in consensus sequence was determined, the mechanisms responsible for the observed increase in virulence of isolate 860/94 in rainbow trout remain unclarified. The possibility remains that genomic changes in other genes or other mechanisms resulting purely from passage in fish, such as the accumulation of defective interfering particles, may contribute to the changes observed at the phenotypic level.

Initial indications are that recent marine VHSV isolates are of lower pathogenicity to salmonids than the classical freshwater strains and as such pose little or no serious threat to the salmonid farming industry (Stone et al. 1997). Since an increase in the virulence of passaged virus for rainbow trout origin has been demonstrated, coupled to the fact that VHSV in freshwater rainbow trout farms may be of marine origin, it would be unwise to ignore the potential threat that marine strains could pose to the fish-farming industry if presented with the opportunity to adapt under intensive culture regimes. Indeed, fish health managers in North America remain concerned that VHSV could mutate and become virulent for rainbow trout (Amos et al. 1998). Regulation to prevent the feeding of unpasteurised marine fish at aquaculture facilities is thus under consideration, in an attempt to prevent the evo- lution of VHSV into a virulent pathogen in North America capable of causing losses such as those seen in Europe (Amos et al. 1998).

Acknowledgements. The authors wish to thank Drs Gael Kurath and Jim Winton for helpful discussion.

\section{LITERATURE CITED}

Amos K, Thomas J, Hopper K (1998) A case history of adaptive management strategies for viral hemorrhagic septicemia virus (VHSV) in Washington state. J Aquat Anim Health 10:152-159

Béarzotti M, Monnier AF, Vende P, Grosclaude J, de Kinkelin P, Benmansour A (1995) The glycoprotein of viral hemorrhagic septicemia virus (VHSV); antigenicity and role in virulence. Vet Res 26:413-422

Benmansour A, de Kinkelin P (1997) Live fish vaccines: history and perspectives. Dev Biol Standard 90:279-289

Benmansour A, Brahimi M, Tuffereau C, Coulon P, Lafay F, Flamand A (1992) Rapid sequence evolution of street rabies glycoprotein is related to the highly heterogeneous nature of the viral population. Virology 187:33-45

Benmansour A, Basurco B, Monnier AF, Vende P, Winton JR, de Kinkelin P (1997) Sequence variation of the glycoprotein gene identifies three distinct lineages within field isolates of viral haemorrhagic septicaemia virus, a fish rhabdovirus. J Gen Virol 78:2837-2846

Bernard J, de Kinkelin P, Bearzotti-Le Berre M (1983) Viral hemorrhagic septicemia of rainbow trout: relation between the $\mathrm{G}$ polypeptide and antibody production in protection of the fish after infection with the F25 attenuated variant. Infect Immun 39:7-14

Burleson FG, Chambers TM, Wiedbrauk DL (1992) Virology, a laboratory manual. Academic Press, London

Fijan N, Sulimanovic D, Bearzotti M, Muzinic D, Zwillenberg LO, Chilmonczyk S, Vautherot JF, de Kinkelin P (1983) Some properties of the epithelioma papulosum cyprini (EPC) cell line from carp (Cyprinus carpio). Ann Inst Past/Virol 134:207-220

Hsu JC (1996) Multiple comparisons: theory and methods. Chapman \& Hall, London

Jørgensen PEV, Einer-Jensen K, Higman K, Winton JR (1995) Sequence comparison of the central region of the glycoprotein gene of neutralizable, non-neutralizable, and serially passed isolates of viral haemorrhagic septicaemia virus. Dis Aquat Org 23:77-82

Kim CH, Winton JR, Leong JC (1994) Neutralization-resistant variants of infectious haematopoietic necrosis virus have altered virulence and tissue tropism. J Virol 68:8447-8453

Kurath G, Dodds JA (1995) Mutation analyses of molecularly cloned satellite tobacco mosaic virus during serial passage in plants: evidence for hotspots of genetic change. RNA 1:491-500

Meyers TR, Winton JR (1995) Viral hemorrhagic septicemia in North America. Annu Rev Fish Dis 5:3-24

Meyers TR, Sullivan J, Emmenegger E, Follet J, Short S, Batts WN, Winton JR (1992) Identification of viral hemorrhagic septicaemia virus isolated from Pacific cod, Gadus macrocephalus in Prince William Sound, Alaska, USA. Dis Aquat Org 12:167-175

Meyers TR, Short S, Lipson K, Batts WN, Winton JR, Wilcock J, Brown E (1994) Association of viral hemorrhagic septicaemia virus with epizootic hemorrhages of the skin in Pacific herring Clupea harengus pallasi from Prince 
William Sound and Kodiak Island, Alaska, USA. Dis Aquat Org 19:27-37

Mortensen HF, Heur OE, Lorenzen N, Otte L, Olesen NJ (1999) Isolation of viral haemorrhagic septicaemia virus from wild marine fish species in the Baltic sea, Kattegat, Skagerrak and the North Sea. Virus Res 63:95-106

Reed LJ, Muench H (1938) A simple method of estimating fifty percent endpoints. Am J Hygiene 27:493-497

Ross K, McCarthy U, Huntly PJ, Wood BP, Stuart D, Rough EI, Smail DA, Bruno DW (1994) An outbreak of viral haemorrhagic septicaemia (VHS) in turbot (Scophthalmus maximus) in Scotland. Bull Eur Assoc Fish Pathol 14:213

Smail DA (1995) Isolation and identification of viral haemorrhagic septicaemia (VHS) virus from north sea cod (Gadus morhua L.). ICES Maricult Comm Rep CM 1995/F:15

Smith DB, McAllister J, Casino C, Simmonds P (1997) Virus 'quasispecies': making a mountain out of a molehill? J Gen Virol 78:1511-1519

Snow M, Cunningham CO, Melvin WT, Kurath G (1999) Analysis of the nucleoprotein gene identifies distinct lineages of viral haemorrhagic septicaemia virus within the European marine environment. Virus Res 63:35-44

Steinhauer DA, Holland JJ (1987) Rapid evolution of RNA viruses. Annu Rev Microbiol 41:409-433

Editorial responsibility: Jo-Ann Leong,

Corvallis, Oregon, USA
Stone DM, Way K, Dixon PF (1997) Nucleotide sequence of the glycoprotein gene of viral haemorrhagic septicaemia (VHS) viruses from different geographical areas: a link between VHS in farmed fish species and viruses isolated from North Sea cod (Gadus morhua L.). J Gen Virol 78: 1319-1326

Traxler GS, Kieser D (1994) Isolation of the North American strain of viral hemorrhagic septicemia virus (VHSV) from herring (Clupea harengus pallasi) in British Columbia. Fish Health Sect Am Fish Soc Newsl 22:8

Weiller G, McClure MA, Gibbs A (1995) Molecular phylogenetic analysis. In: Gibbs A, Calisher $\mathrm{CH}$, Garcia-Arenal F (eds) Molecular basis of virus evolution. Cambridge University Press, Cambridge, p 553-585

Winton JR (1992) Evolution of fish rhabdoviruses. In: Kimura $\mathrm{T}$ (ed) OJI International Symposium on Salmonid Diseases. Hokkaido University Press, Sapporo, p 88-95

Winton JR, Batts W, Deering R, Brunson R, Hopper K, Nishizawa T, Stehr C (1991) Characteristics of the first North American isolates of viral hemorrhagic septicaemia virus. In: 2nd International Symposium on Viruses of Lower Vertebrates. Oregon State University, Corvallis, p 43-50

Wolf K (1988) Fish viruses and fish viral diseases. Cornell University Press, Ithaca

Submitted: January 15, 2000; Accepted: April 26, 2000 Proofs received from author(s): July 4, 2000 